\title{
The Concentration of Immunoglobulins $A, G$, and $M$ in Cow Milk and Blood in Relation with Cow Seasonal Keeping and Pathogens Presence in the Udder
}

\author{
Iveta Kocina* \\ Food and Veterinary Service \\ Vita Antāne \\ Clinical Institute of the Faculty of Veterinary Medicine, LLU \\ Ivars Lūsis \\ Institute of Food and Environmental Hygiene of the Faculty of Veterinary Medicine, LLU
}

\begin{abstract}
Recent studies show that immunoglobulins A, G, and M contribute significantly to the maintenance of udder health. Unfortunately, the concentration of immunoglobulins in cow milk during the middle period of lactation is low therefore the question of how to stimulate and maintain a sufficient level and spectrum of antibodies in the udder is topical. The aim of the present study was to evaluate the dynamics of the amount of immunoglobulins $\mathrm{A}, \mathrm{G}$, and $\mathrm{M}$ in cow milk and blood serum in relation with the cow seasonal keeping and presence of pathogens in the udder. The experimental part of the study was carried out on the dairy farm "Pērles", Valmiera region. Cows were kept in a cold loose housing system, grouped and fed differently depending on cow productivity and lactation period. Two times in the housing period and two times in the grazing period milk and blood were sampled from 16 dairy cows and examined for the concentration of immunoglobulins A, G, and M and for the presence of pathogens. Cows for the study were selected with the aim to analyze the milk obtained from clinically healthy udder quarters of cows of similar-age and productivity in the middle stage of lactation. It was determined that seasonal keeping of cows had significantly affected the concentration of immunoglobulins $\mathrm{G}$ and $\mathrm{A}$ in milk $(p<0.001)$, and of immunoglobulins $\mathrm{A}, \mathrm{G}$, and $\mathrm{M}$ in blood serum $(p<0.001)$. Some pathogenic bacteria species infecting the udder quarters had considerably influenced the values of immunoglobulins $\mathrm{G}, \mathrm{A}$, and $\mathrm{M}(p<0.05, p<0.001$, and $p<0.001$, respectively) in blood serum. A wide variation amplitude of immunoglobulin $\mathrm{G}, \mathrm{A}$, and $\mathrm{M}$ concentration in milk and blood serum was observed, which indicates the important role of the individual factor of an animal in the formation of animal defence response.
\end{abstract}

Key words: immunoglobulins A, G, and M; mammary gland; housing and grazing period; pathogens.

\section{Introduction}

With the aim of facilitating resistance of dairy cows against mastitis caused by pathogenic microflora, intensive investigations in immunology have been carried out almost for a century. However, remarkable contradictions still exist in this field of research and expected achievements are delayed. For quite a long time there were two types of opinions on immunological intervention in the mastitis control programs. The first one expresses the assumption that control of mastitis and promotion of immunological defence response in the udder are possible by improving the management measures (Craven, Williams, 1985; Barkema, Schukken et al., 1999). The second, different opinion is that in mastitis control, vaccination plays the most important role (Kenny, Bastida-Corcvera, Norcross, 1992).

Natural immunological protective reactions of the animal, if they are not in a suppressed condition, can successfully restrict and eliminate the udder infection (Sandholm, Pyörälä, 1995). If the activity of the immunological system is reduced or the virulence of pathogenic microorganisms is high, infection, partly eliminated, may continue for a longer period, and usually this process becomes apparent as subclinical or chronic mastitis (Ali-Vehmas, Sandholm, 1995). Investigations show evidence that humoral immunity components such as immunoglobulins A and G play an important role in immunological defence response of 
the cow udder (Marnila, Korhonen, 2002; Korhonen, Kaartinen, 1995). Unfortunately, concentration of immunoglobulins in cow milk is low in the middle phase of lactation. That is why the question of how to stimulate and maintain a sufficient level and spectrum of antibodies in the udder for mastitis prevention is topical (Kenny, Bastida-Corcvera, Norcross, 1992). Different authors have indicated that concentration of immunoglobulins $\mathrm{A}, \mathrm{G}$, and $\mathrm{M}$ in the cow milk varies not only depending on the degree of infection of the udder but it is also affected considerably by the cow age, lactation period, keeping conditions, and feeding (Guidry, Paape, Pearson, 1980; Guidry, Butler et al., 1980; Guidry, Miller, 1986; Butler, 1994; McFadden, Besser, Barrington, 1997; Zagorska, Ciproviča, Mik̦elsone, 2007).

During the last decade, investigations have been carried out to find out and to understand possibilities of intensifying the activity of immunoglobulins A, G, and $\mathrm{M}$ in the mammary gland. Studies have mainly analyzed experimentally caused acute mastitis; some studies have evaluated the dynamics of immunoglobulins in cow milk in cases of subclinical bacterial udder infections. Scientists from different countries in the world express rather contradictory opinions on the importance of immunoglobulins $\mathrm{A}, \mathrm{G}$, and $\mathrm{M}$ (further in the text $\operatorname{IgA}, \mathrm{IgG}$, and IgM) in maintenance of the udder health, as well as evaluate differently the role of different factors in the regulation of the concentration of above-mentioned defence components. This suggests that dynamics of IgA, IgG, and IgM in cow milk should be evaluated in relation to cow age, lactation period, functional status and health of the udder, keeping conditions, and seasonal effect.

In order to understand and evaluate the role of $\operatorname{IgA}, \operatorname{IgG}$, and $\operatorname{IgM}$ in maintaining the udder health, the dynamics of their amounts in cow milk and blood serum in relation with pathogenic bacteria presence in the mammary gland and cow seasonal keeping was investigated. In Latvia, such kind of investigation has not been carried out previously.

\section{Material and Methods}

The experiment was carried out on the dairy farm "Pērles", Valmiera region. The IgA, IgG, and IgM concentrations in milk and blood serum were estimated at "Rīgas Reprodukcijas Centrs" Ltd. (Riga Reproduction Centre). Milk microbiological examination was performed in the Laboratory of Herd Health and Reproduction Problem of the Faculty of Veterinary Medicine of the Latvia University of Agriculture.

The dairy herd consisted of 75 cows with the average milk yield of $7156 \mathrm{~kg}$ per year. The average fat content in milk was $4.2 \%$, protein content $-3.3 \%$, somatic cell count $\quad-255000$ cells per millilitre $\left(\mathrm{m} \mathrm{L}^{-1}\right)$. The age of cows was from two to eight years, and the average lactation number was 3.5 lactations.

The cows were kept in a cold loose housing system, grouped and fed differently depending on their productivity and lactation period. The cow rations included silage, hay, mixed concentrated feed, fodder beet as well as feed additives. Conifer sawdust was used as the bedding material. During the summer-autumn period cows were grazing in the day pasture, but in winter and spring they were kept in a barn. The cows were milked in a "herringbone" type parlour twice a day - at 6 a.m. and 6 p.m. Before milking, teats were cleaned with single-use napkins. Milk from each quarter first was squirted into a separate cup with a black bottom, and the milk quality was evaluated. Every time after milking, cow teats were disinfected. As four cows were simultaneously milked in the milking parlour, the milkman had a possibility of following systematically the process of milking of each cow.

Milk and blood were sampled four times from 16 cows as the herd-representing samples. Milk was obtained from clinically healthy udder quarters of cows of similar age and productivity $(22-25 \mathrm{~kg}$ of milk per day) in the middle stage of lactation (2nd and 3rd lactation). In total, 214 milk samples were analyzed.

The clinical examination of mammary gland was performed in compliance with the criteria set by the IDF (International Dairy Federation, 1987). Evaluation of the milk samples was made according to the method described by Sandholm and Pyörälä (1995). Milk samples were collected for laboratory examination aseptically in accordance with the method recommended by the ISO $707\left(^{1}\right)$ standard. Microbiological examination for identification of pathogenic microorganisms was made as soon as the samples were delivered to the Laboratory. Standard procedures for identifying pathogenic microorganisms in milk were performed in compliance with the IDF (International Dairy Federation, 1981) criteria and the method described by Quinn, Carter et al. (2000).

For estimation of the immunoglobulin A, G, and $M$ concentration in milk and blood serum, the following reagent kits were used: "MIKROANALIZ 
IgG”, quality standard TY 9398-337-00155866-99; “MIKROANALIZ IgA", quality standard TY 9398335-00155866-99; and "MIKROANALIZ IgM", quality standard TY 9398-336-00155866-99. The kits were made in the joint stock company "НПО СИНЕКОЗ", and they are applicable for estimation of immunoglobulins A, G, and M by turbidimetry method.

The obtained data were statistically processed by using SPSS program 11.0 and Microsoft Excel packages.

Statistical data - mean parameters, standard deviation $\overline{\boldsymbol{x}} \pm \mathrm{SD}$, and minimum and maximum values - were calculated. The advanced hypotheses were verified by the $p$ value method, and the calculated $p$ value was compared at a significance level $\alpha=0.05$ (Arhipova, Bāliņa, 2003).

\section{Results and Discussion}

The values of IgA, IgG, and IgM in milk and blood serum

The amount of $\operatorname{IgA}, \operatorname{IgG}$, and IgM in milk varies remarkably among some individuals (Guidry, Miller, 1986), and all factors influencing their concentration are undiscovered yet (Butler, 1994; Korhonen, Marnila, Gill, 2000; Krol, Litvinczuk et al., 2010). Authors have reported that in healthy cow milk during the middle stage of lactation, the concentration of all classes of immunoglobulins is low, but it increases during the udder inflammation (Sandholm, Korhonen, 1995; Korhonen, Marnila, Gill, 2000).

Immunoglobulin values in the milk obtained in our research, and the standards given in the literature are summarized in Table 1. Compared to the immunoglobulin standards in healthy cow milk as indicated by some foreign authors, $\operatorname{IgA}$, $\operatorname{IgG}$, and $\operatorname{IgM}$ concentration in our research was higher, but $\operatorname{IgA}$ and $\operatorname{IgM}$ values agreed with the results of another research carried out in Latvia (Zagorska, Ciproviča, Miķelsone, 2007). The values of all immunoglobulin classes in milk, especially $\operatorname{IgM}$, varied in wide ranges in our research. Whereas in blood serum, IgG and $\operatorname{IgM}$ mean values (2.34 $\pm 0.91 \mathrm{~g} \mathrm{~L}^{-1}$ and $0.53 \pm 0.52 \mathrm{~g} \mathrm{~L}^{-1}$, respectively) were lower than those indicated by other authors, but IgA concentration slightly exceeded them (Butler, 1994).

Our obtained results possibly indicate that in the case of latent and subclinical udder inflammation, IgG and IgM immigration from the blood circulation into the udder tissue was intensified in order to protect the udder from the manifestation of infection
(Lascelles, 1979), and in that way the concentration of these immunoglobulins increased in milk but decreased in the blood serum. Other authors have reported that the increase in immunoglobulin $\mathrm{G}$ and $\mathrm{M}$ concentration was not observed when cows did not have acute udder inflammation (Rainard, Caffin, 1983). In addition, lots of other milk-blood barrier regulating and influencing factors are possible, which determines immunoglobulin immigration from the blood circulation into the mammary gland tissue (Lewis-Jones, Lewis-Jones et al., 1985).

In our research, the IgA concentration in blood serum agreed with that described in the literature, which possibly suggests that the IgA needed for the udder tissue protection, in contrast to $\operatorname{IgG}$ and IgM, basically is produced by local plasmatic cells and does not immigrate from the blood circulation (Watson, 1980; Guidry, Butler et al., 1980).

The concentration of $\operatorname{IgA}$, IgG, and $\operatorname{IgM}$ in milk and blood serum during the housing and grazing period

It is mentioned in the literature that immunoglobulin amount in blood serum and milk in cattle varies significantly depending on the season and reaches its highest concentration in milk in the spring and summer (Guidry, Miller, 1986; Konuspayeva, Faye, 2007). Also our investigation confirmed that the cow seasonal keeping significantly affects the concentration of $\operatorname{IgA}$ and $\operatorname{IgG}$ in milk, and of $\operatorname{IgA}$, $\mathrm{IgG}$, and $\mathrm{IgM}$ in the blood serum, and that values of these immunoglobulins differ significantly $(p<0.001)$ in the housing and grazing period.

Figure 1 shows IgA, IgG, and IgM values in milk during the housing and grazing period as well as dispersion of these values.

Immunoglobulin $\mathrm{G}$ in milk reached the highest mean value of $2.26 \pm 0.91 \mathrm{~g} \mathrm{~L}^{-1}$ during the housing period when that was the predominating globulin in the cow milk. In the grazing period, the mean $\mathrm{IgG}$ value in milk samples was $1.83 \pm 0.67 \mathrm{~g} \mathrm{~L}^{-1}$, and its quantitative predominance over other immunoglobulins in milk was small.

Immunoglobulin A in milk reached its highest mean value of $1.83 \pm 0.61 \mathrm{~g} \mathrm{~L}^{-1}$ in the grazing period, whereas in the housing period it was two times lower, namely, $0.93 \pm 0.37 \mathrm{~g} \mathrm{~L}^{-1}$.

The mean values of immunoglobulin $\mathrm{M}$ in milk in the grazing and housing period were approximately equal - $1.35 \pm 0.88 \mathrm{~g} \mathrm{~L}^{-1}$ and $1.31 \pm 1.00 \mathrm{~g} \mathrm{~L}^{-1}$. Whereas results of other investigations in Latvia 
Immunoglobulin $\mathrm{G}, \mathrm{A}$, and $\mathrm{M}$ values $\left(\mathrm{g} \mathrm{L}^{-1}\right)$ in milk obtained in the present research, and standards given in the literature

\begin{tabular}{|c|c|c|c|}
\hline \multirow{2}{*}{$\begin{array}{l}\text { Immunoglobulin } \\
\text { class }\end{array}$} & \multicolumn{2}{|c|}{ Data of our studies } & \multirow{2}{*}{$\begin{array}{l}\text { Standard in } \\
\text { healthy cows }\end{array}$} \\
\hline & $\begin{array}{c}\text { mean value, standard } \\
\text { deviation }\end{array}$ & $\begin{array}{l}\text { ranges } \\
\text { of values }\end{array}$ & \\
\hline $\operatorname{IgG}$ & $2.05 \pm 0.83$ & $0.16-4.30$ & $\begin{array}{c}0.52 ; 1.40 \\
\text { Sandholm, Korhonen, 1995; } \\
\text { Liu, Wang et al., } 2009\end{array}$ \\
\hline $\operatorname{Ig} \mathrm{A}$ & $1.36 \pm 0.67$ & $0.48-4.95$ & $\begin{array}{c}0.10 \\
\text { Sandholm, Korhonen, } 1995 \\
0.71-1.12 \\
\text { Zagorska, Ciproviča, } \\
\text { Miķelsone, 2007 }\end{array}$ \\
\hline $\operatorname{IgM}$ & $1.33 \pm 0.94$ & $0.00-6.17$ & $\begin{array}{c}0.12 \\
\text { Sandholm, Korhonen, } 1995 \\
1.23-1.65 \\
\text { Zagorska, Ciproviča, } \\
\text { Miķelsone, } 2007\end{array}$ \\
\hline
\end{tabular}

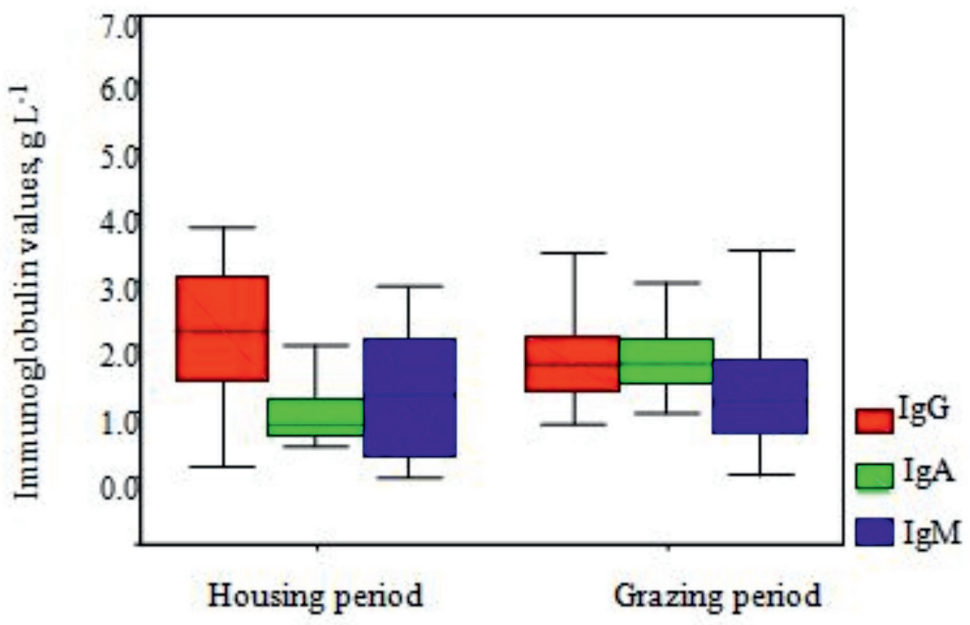

Fig. 1. Immunoglobulin $\mathrm{G}, \mathrm{A}$, and $\mathrm{M}$ values in milk $\left(\mathrm{g} \mathrm{L}^{-1}\right)$ in the housing and grazing period.

have proved that $\mathrm{IgG}$ concentrations in milk did not differ significantly depending on the cow keeping conditions (conventional and biological farming); in contrast, $\operatorname{IgA}$ and $\operatorname{IgM}$ values differed significantly (Zagorska, Ciproviča, Miķelsone, 2007).

It was established in our study that IgA concentration in milk had increased significantly in cows in the transition period from housing to grazing $(p<0.001)$, reaching its highest mean value in the grazing period. During the grazing period the udder is subjected to more intensive environmental influence and various types of irritants. The high IgA concentration in the grazing period most likely indicates that in protection of the mammary gland tissue, primary and most important role belongs exactly to $\operatorname{IgA}$. Other authors have established that $\operatorname{Ig} \mathrm{A}$ is involved in the udder tissue defence already in early stage of tissue irritation, inhibits bacteria binding to the udder epithelial cells, agglutinates them, and neutralizes bacterial toxins (Watson, 1980; Korhonen, Kaartinen, 1995). Some different results demonstrate that secretory $\operatorname{IgA}$ in the cow udder is inactive because it binds with milk fat globules; consequently, it is unimportant in the udder tissue protection (Lascelles, 1979; Tizard, 2000).

Our research demonstrated that during the housing period IgG and IgM content in milk samples varied within a much wider range than in the grazing period. 


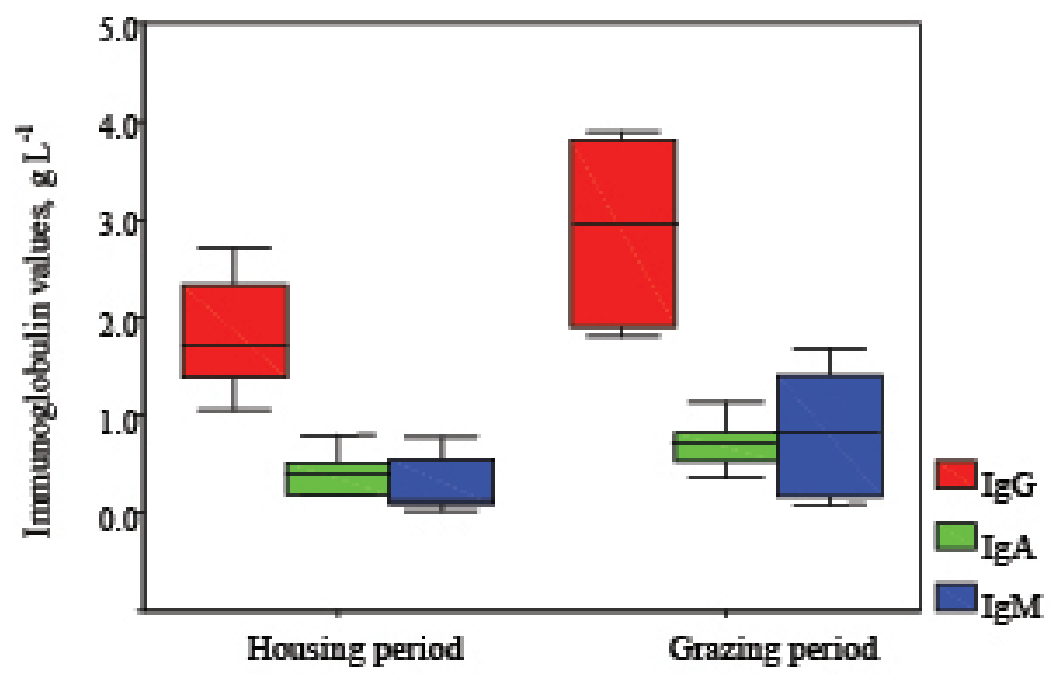

Fig. 2. Immunoglobulin $\mathrm{G}, \mathrm{A}$, and $\mathrm{M}$ values in cow blood serum $\left(\mathrm{g} \mathrm{L}^{-1}\right)$ during the housing and grazing period.

The range of IgA values was not so much expressed; however, comparatively greater IgA value variations were observed in the grazing period. Some sample values, especially in the grazing period, were beyond the standard deviation limits, which points to the important role of the individual factor in production of immunoglobulins.

$\mathrm{IgA}, \mathrm{IgG}$, and $\operatorname{IgM}$ values in blood serum in the housing and grazing period are presented in Figure 2.

In blood serum, the highest mean values of $\mathrm{IgG}, \operatorname{Ig} \mathrm{A}$, and $\operatorname{IgM}$ were determined in the grazing period $\left(2.98 \pm 0.89 \mathrm{~g} \mathrm{~L} \mathrm{~L}^{-1}, 0.70 \pm 0.20 \mathrm{~g} \mathrm{~L}^{-1}\right.$, and $0.84 \pm 0.61 \mathrm{~g} \mathrm{~L} \mathrm{~L}^{-1}$, respectively), when they were considerably greater $(p<0.001)$ than in the housing period. That indicates the immune system activation processes occurring in relation with the placing of cows on pasture, opportunities to move, availability of a more valuable and good quality feed during the grazing period as well as the increase in udder infection and irritation cases.

The values of $\operatorname{IgA}$, IgG, and IgM in milk and blood serum in relation with the infection of udder quarters

There are different investigation results of the quantity of immunoglobulins A, G, and M in a normal and pathogenic microorganism-infected mammary gland, and most often they provide information about the immunoglobulin dynamics in cow milk in the case of acute and clinical forms of mastitis. As the literature data indicate, $\operatorname{IgA}, \operatorname{IgG}$, and $\operatorname{IgM}$ amount in milk increases considerably during the udder inflammation when they get actively involved into immunological responses of mammary gland against the pathogens invading the udder (Butler, 1994; McFadden, Besser et al., 1997). In the diseased udder milk their concentration might increase 3-5 (Sandholm, Korhonen, 1995), and even 10 and more times (Korhonen, Kaartinen, 1995).

The authors of the present study carried out investigations to find out $\operatorname{IgA}, \operatorname{IgG}$, and $\operatorname{IgM}$ values in the cow milk and blood serum when the cows were not diagnosed acute and clinical udder inflammation.

IgG mean values in milk samples with pathogenic agents and without pathogens differed slightly (2.23 $\pm 0.84 \mathrm{~g} \mathrm{~L}^{-1}$ and $2.19 \pm 0.69 \mathrm{~g} \mathrm{~L}^{-1}$, respectively). IgA mean value in samples without pathogenic agents was slightly higher than in samples with mastitis agents $\left(1.49 \pm 0.86 \mathrm{~g} \mathrm{~L}^{-1}\right.$ and $1.23 \pm 0.57 \mathrm{~g} \mathrm{~L}^{-1}$, respectively), and also IgM mean value was higher in samples without pathogenic agents $\left(1.71 \pm 0.87 \mathrm{~g} \mathrm{~L}^{-1}\right.$ and $1.45 \pm 0.87 \mathrm{~g} \mathrm{~L}^{-1}$, respectively).

It can be concluded that the mean values of $\mathrm{IgG}$, $\operatorname{Ig} \mathrm{A}$, and $\operatorname{IgM}$ differed insignificantly both in milk samples with and without pathogenic mastitis agents $(p>0.05)$.

In blood serum samples, IgG mean value $\left(2.17 \pm 0.77 \mathrm{~g} \mathrm{~L}^{-1}\right)$ was greater in cows in which milk pathogenic microorganisms were discovered. In the blood serum of cows which milk was pathogen free $\mathrm{IgG}$ mean value was $2.01 \pm 0.67 \mathrm{~g} \mathrm{~L}^{-1}$. Also the mean values of IgA in blood serum were similar both in cows with milk containing pathogenic microorganisms and in cows with pathogen-free milk $-0.42 \pm 0.22 \mathrm{~g} \mathrm{~L}^{-1}$ and $0.44 \pm 0.16 \mathrm{~g} \mathrm{~L}^{-1}$, respectively. The same tendency was also shown by $\operatorname{IgM}$ mean values: $0.32 \pm 0.41 \mathrm{~g} \mathrm{~L}^{-1}$ in 


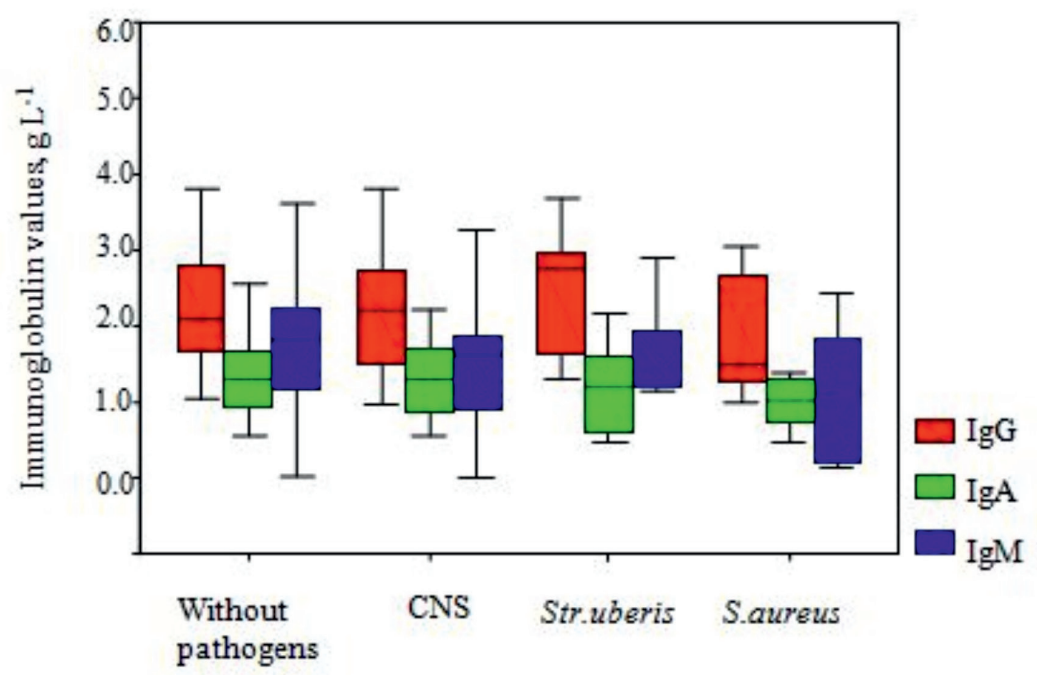

Fig. 3. Immunoglobulin $\mathrm{G}, \mathrm{A}$, and $\mathrm{M}$ values $\left(\mathrm{g} \mathrm{L}^{-1}\right)$ in cow blood serum in relation with the infection of udder quarters.

blood serum of cows with milk containing pathogenic microorganisms, and $0.30 \pm 0.31 \mathrm{~g} \mathrm{~L}^{-1}$ in blood serum of cows with pathogen-free milk. A conclusion can be drawn that mean parameters of immunoglobulins $\mathrm{G}$, $\mathrm{A}$, and $\mathrm{M}$ in the blood serum differed insignificantly depending on the udder infection in cows $(p>0.05)$.

Figure 3 shows $\operatorname{IgA}, \operatorname{IgG}$, and $\operatorname{IgM}$ values and their amplitude range in the cow blood serum in relation with the udder quarter infection. The mean parameters are very similar in both groups; however, the amplitude range is larger in the blood serum of cows which udder was infected, and especially pronounced it is in the $\operatorname{IgG}$ maximum values. In some samples immunoglobulin values were beyond the standard deviation limits, which suggests the important role of the individual factor of an animal in production of immunoglobulins. This finding agrees with the results of other researchers (Guidry, Miller, 1986).

There are research findings that $\operatorname{IgA}, \operatorname{IgG}$, and IgM concentrations in the cow milk and blood considerably increase with the increase in udder infections (Butler, 1994; Korhonen, Marnila, Gill, 2000). It has been observed that in the case of clinical mastitis, immunoglobulins in cow milk may increase noticeably, especially during an acute udder infection (Avery, Gordon, 1991; Korhonen, Marnila, Gill, 2000).

The results of our research, similarly to the investigation made by Guidry, Paape and Pearson (1980), demonstrated that for cows with latent and subclinical udder inflammation, $\operatorname{IgA}, \operatorname{IgG}$, and IgM values in milk and blood serum increased insignificantly in comparison with healthy cows. This allows concluding that large amounts of immunoglobulins $\mathrm{A}, \mathrm{G}$, and $\mathrm{M}$ in the udder provided the udder protection both in healthy cows and in cows diagnosed the presence of pathogenic microorganisms. The increased concentration of $\operatorname{IgG}$ and $\operatorname{IgM}$ in the udder was maintained by their immigration from the blood circulation; IgA concentration, in its turn, was maintained by its elevated production in the udder tissue.

Performing an in-depth investigation, $\operatorname{IgG}, \operatorname{IgA}$, and IgM concentrations in the cow milk and blood serum were established in relation with the relevant pathogens present in the udder (Fig. 4).

In milk samples, the $\operatorname{IgG}$ mean value was highest $\left(2.70 \pm 0.32 \mathrm{~g} \mathrm{~L}^{-1}\right)$ in the case of Str. uberis infection, but the lowest $\left(1.35 \pm 0.32 \mathrm{~g} \mathrm{~L}^{-1}\right)$ - in case of $S$. aureus infection, which was even lower than in healthy quarter milk. The largest amplitude range of immunoglobulin values was observed in the case of coagulase negative staphylococci (CNS) infection. The lowest IgA value $\left(1.20 \pm 0.42 \mathrm{~g} \mathrm{~L}^{-1}\right)$ was observed in the case of $S$. aureus infection, and it was slightly higher in case of CNS and Str. uberis infections $\left(1.30 \pm 0.21 \mathrm{~g} \mathrm{~L}^{-1}\right.$ and $1.29 \pm 0.44 \mathrm{~g} \mathrm{~L}^{-1}$, respectively). Also IgM values in the infected quarter milk were lower than in healthy udder quarter milk. Similarly to $\operatorname{IgG}$ and $\operatorname{IgA}$, the lowest IgM mean value $\left(1.27 \pm 0.49 \mathrm{~g} \mathrm{~L}^{-1}\right)$ was observed in $S$. aureus infected quarter milk (Fig. 4). The results of our investigation confirm that immunoglobulin $\operatorname{IgG}, \operatorname{Ig} \mathrm{A}$, and $\operatorname{IgM}$ concentrations in milk were not influenced by the pathogenic agent type present in 


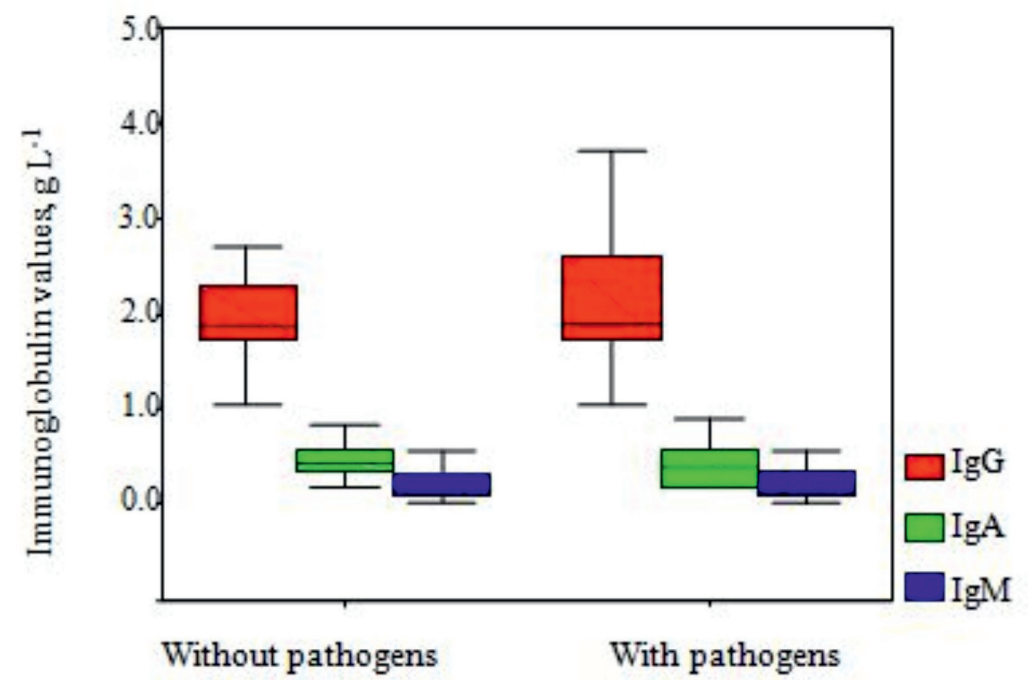

Fig. 4. Immunoglobulin $\mathrm{G}, \mathrm{A}$, and $\mathrm{M}$ values $\left(\mathrm{g} \mathrm{L}^{-1}\right)$ in milk in relation with pathogenic agents in the udder quarters.

the udder quarter $(p>0.05)$. However, researchers Rainard and Caffin (1983) and Korhonen, Marnila, Gill (2000) have established that immunoglobulin values in milk were influenced by the pathogens type in the udder.

In blood serum samples, $\operatorname{IgG}, \operatorname{Ig} A$, and $\operatorname{IgM}$ reached their highest mean values $\left(2.62 \pm 0.74 \mathrm{~g} \mathrm{~L}^{-1}\right.$, $0.51 \pm 0.24 \mathrm{~g} \mathrm{~L}^{-1}$, and $0.50 \pm 0.46 \mathrm{~g} \mathrm{~L}^{-1}$, respectively) in the case of $S$. aureus-caused udder infection, whereas presence of CNS and Str.uberis pathogens in mammary gland could not cause increase in the immunoglobulin concentrations in blood. The mean values of immunoglobulins $\mathrm{G}, \mathrm{A}$, and $\mathrm{M}$ in blood serum differed significantly depending on the type of pathogenic mastitis agent present in the udder quarter $(\operatorname{IgG} p<0.05, \operatorname{IgA} p<0.001$, and $\operatorname{IgM}$ $p<0.001$, respectively). Our research suggests that during a latent and subclinical udder inflammation only $S$. aureus could cause increase in the amounts of immunoglobulins $\mathrm{G}, \mathrm{A}$, and $\mathrm{M}$ in the cow blood serum.

The data in the literature indicate that the immunoglobulin concentration in milk and blood should be evaluated in interconnection with pathogenic microorganism species causing mastitis and with the character and duration of inflammation (Rainard, Caffin, 1983; Anderson, Shanks et al., 1986). Immunoglobulin concentration in milk has increased considerably during an acute udder inflammation (Guidry, Paape, Pearson, 1980; Östensson, Lun, 2008), whereas during chronic mastitis, for example, in the case of $S$. aureus mastitis, differences in the amount of immunoglobulin concentrations in milk and blood have not been established (Doymaz, Sordillo et al., 1988).

Hill, Finch et al. (1994) have found that during Str. uberis-induced udder inflammation, immunoglobulin opsonic activity in milk and blood serum is low, therefore specific antibodies do not protect the udder in the case of this infection. Results of their investigation also confirmed the low activity of $\mathrm{IgA}, \mathrm{IgG}$, and IgM in blood serum in the case of Str. uberis udder infection, while in the milk, during this infection, IgG concentration was elevated.

The concentration of $\operatorname{IgA}, \operatorname{IgG}$, and $\operatorname{IgM}$ in milk during the housing and grazing period in relation with the infection of udder quarters

Evaluating the immunoglobulin $\mathrm{G}, \mathrm{A}$, and $\mathrm{M}$ concentration in milk in the housing and grazing period in relation with the presence of pathogenic agents in udder, we came to a conclusion that interaction effect of seasonal keeping and pathogenic agents insignificantly affect the $\operatorname{IgA}, \operatorname{IgG}$, and $\operatorname{IgM}$ amounts in milk $(p>0.05)$, with the exception of some tendencies.

The IgG mean value in milk during the housing period (compared to grazing period) was found to be higher both in samples with pathogenic agents and in pathogen-free samples, whereas in the grazing period IgG concentration was higher in milk samples of non-infected udder quarters. IgA mean value in the grazing period (compared to housing period) was higher in samples both with pathogenic agents 


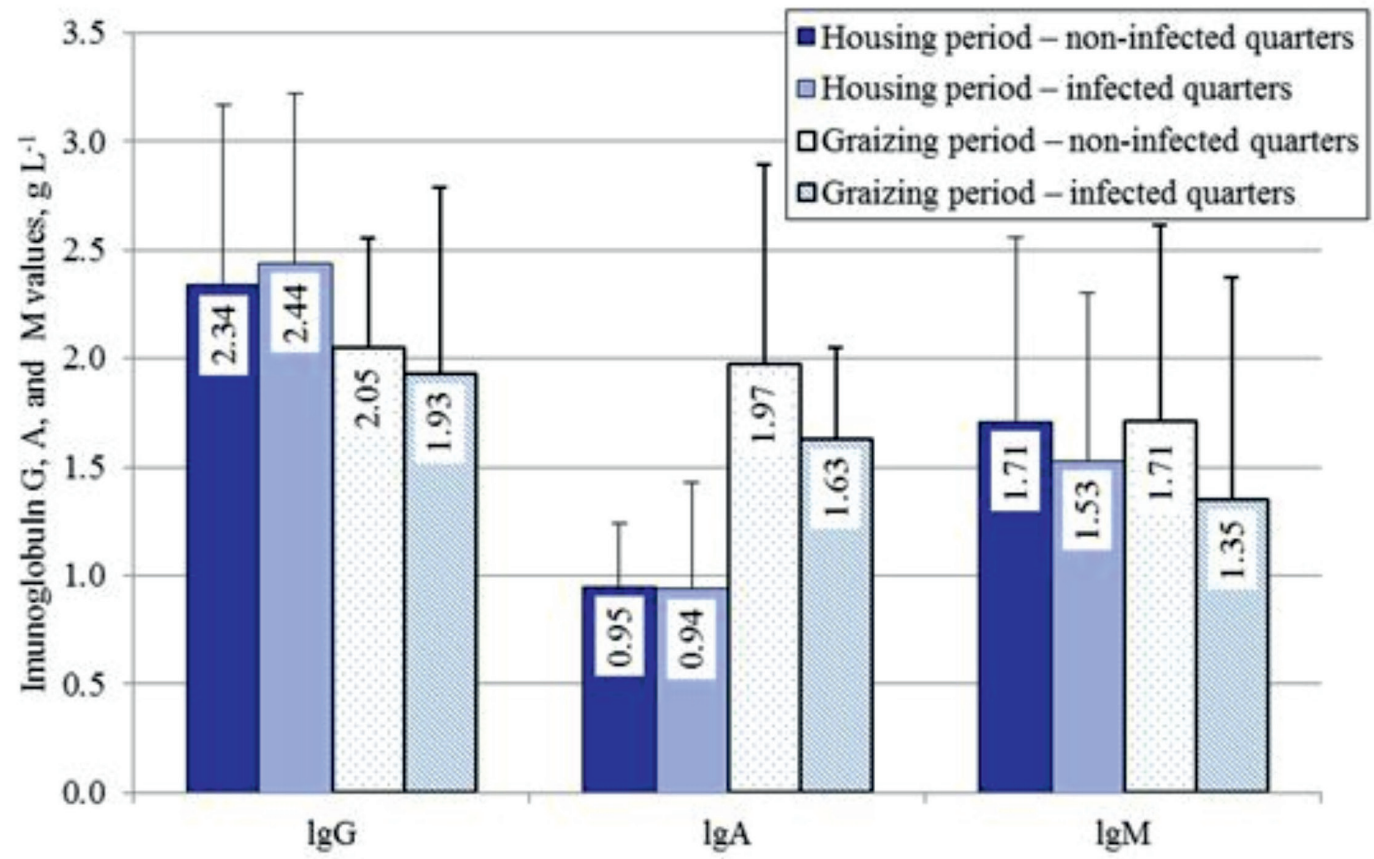

Fig. 5. The dynamics of immunoglobulin $\mathrm{G}, \mathrm{A}$, and $\mathrm{M}\left(\mathrm{g} \mathrm{L}^{-1}\right)$ values in milk during the housing and grazing period in relation with the udder infection.

and without them; moreover, similarly to $\operatorname{IgG}$ value, in the grazing period a larger IgA amount was established in the milk samples of non-infected udder quarters. Our results confirm the literature data that the $\mathrm{IgG}$ and $\operatorname{IgA}$ concentration increase in milk has a seasonal character (Konuspayeva, Faye et al., 2007); moreover, in the grazing period immunoglobulin $\mathrm{G}$ and A concentration has a tendency to increase in non-infected quarter milk. As to IgM concentration in milk, its mean value in the housing and grazing period was higher in non-infected quarter milk, and during a year it remained approximately the same, while in the infected quarter milk it increased rapidly during the housing period. Analyzing IgM values in milk it was ascertained that under the influence of seasonal keeping the immunoglobulin concentration increased only in the infected quarter milk (Fig. 5).

\section{Conclusions}

1. The seasonal keeping of cows significantly affected the concentration of immunoglobulins $\mathrm{G}$ and $\mathrm{A}$ in milk $(p<0.001)$ as well as of immunoglobulins $\mathrm{G}, \mathrm{A}$, and $\mathrm{M}$ in blood serum $(p<0.001)$.

2. Compared with the housing period, concentration of immunoglobulin $\mathrm{A}$ in milk as well as of immunoglobulins $\mathrm{G}, \mathrm{A}$, and $\mathrm{M}$ in blood serum increased significantly $(p<0.001)$ in the grazing period; whereas in the housing period immunoglobulin $\mathrm{G}$ in milk increased significantly $(p<0.001)$.

3. Concentrations of immunoglobulins $\mathrm{G}, \mathrm{A}$, and $M$ differed insignificantly both in subclinically infected and in healthy quarter milk $(p>0.05)$, but in blood serum they were significantly affected by several pathogenic bacteria species infecting the udder quarters $(p<0.05, p<0.001$, and $p<0.001$, respectively).

4. A wide variation amplitude of immunoglobulin $\mathrm{G}, \mathrm{A}$, and $\mathrm{M}$ concentrations was observed in milk and blood serum, which indicates the important role of the animal individual factor in the formation of immunological defence response.

\section{References}

1. Ali-Vehmas, T., \& Sandholm, M. (1995). Balance between bacteria and host - the bacteria point of view. In M. Sandholm, T. Honkanen, T. Honkanen-Buzalski, L. Kaartinen, \& S. Pyorala (Eds.), The Bovine Udder and Mastitis (pp. 49-58). Iyvaskyla, Finland: Gummerus Kirjapaino Oy.

2. Anderson, K. L., Shanks, R. D., Whitmore, H. L., Davis, L. E., \& 
Gustafsson, B. K. (1986). Endotoxin induced bovine mastitis: immunoglobulin's phagocitosis and effect of flunixin meglumine. American Journal of Veterinary Research, 47(11), 2405-2410.

3. Arhipova, I., \& Bāliņa, S. (2003). Statistika Ekonomikā. Risinājumi ar SPSS un Microsoft Exel. Rīga: Datorzinību centrs.

4. Avery, V. M., \& Gordon, D. L. (1991). Antibacterial properties of breast milk: requirements for surface phagocytosis and chemiluminescence. European Journal of Clinical Microbiology and Infectious Diseases, 10, 1034-1039.

5. Barkema, H. W., Schukken, Y. H., Lam, T. J., Beiboer, M. L., Benedictus, G., \& Brand, A. (1999). Management practices associated with the incidence rate of clinical mastitis. Journal of Dairy Science, (82), 1643-1654.

6. Butler, J. E. (1994) Passive immunity and immunoglobulin diversity. Indigenous Antimicrobial Agents of Milk - Recent Developments. IDF Special Issue No. 9404 (4), 14-50.

7. Craven, N., \& Williams, M. R. (1985). Defenses of the bovine mammary gland against infection and prospects for their enhancements. Veterinary Immunology and Immunopathology, 10, 71-127.

8. Doymaz, M. Z., Sordillo, L. M., Oliver, S. P., \& Guidry,A. J. (1988). Effect of S.aureus mastitis on bovine mammary gland plasma cell populations and immunoglobulin concentration in milk. Veterinary Immunology and Immunopathology, 20(1), 87-93.

9. Guidry, A. J., Butler, J. E., Pearson, R. E., \& Weinland, B. T. (1980). IgA, IgG 1, IgG2, IgM, and BSA in serum and mammary secretion throughout lactation. Veterinary Immunology and Immunopathology, 1, p. 329.

10. Guidry, A. J., \& Miller, R. H. I. (1986). Immunoglobulin isotype concentrations in milk as affected by stage of lactation and parity. Journal of Dairy Science, 69, 1799-1805.

11. Guidry, A. J., Paape, M. J., \& Pearson, R. E. (1980). Effect of udder inflammation on milk immunoglobulins and phagocytosis. American Journal of Veterinary Research, 41(5), 751-753.

12. Hill, A. W, Finch, J. M, Field, T. R., \& Leigh, J. A. (1994). Immune modification of the pathogenesis of Struberis mastitis in the dairy cow. FEMS.
Immunology and Medical Microbiology, 8(2), 109-117.

13. International Dairy Federation. (1981). Laboratory methods for use in mastitis work. Bulletin, 132, p. 27.

14. International Dairy Federation. (1987). Bovine mastitis, definitions and guidelines for diagnosis. Bulletin, 221, 3-16.

15. Kenny, K., Bastida-Corcvera, F., \& Norcross, N. L. (1992). The enhancement of mammary gland immunity through vaccination. In A.H. Andrews (Ed.), Bovine Medicine: Diseases and Husbandry of Cattle (pp. 335-350). Oxford: Blackwell Science Ltd.

16. Konuspayeva, G., Faye, B., Loiseau, G., \& Levieux, D. (2007). Lactoferrin and immunoglobulin contents in camels milk from Kazahstan. Journal of Dairy Science, 90, 38-46.

17. Korhonen, H., \& Kaartinen, L. (1995). Changes in the composition of milk induced by mastitis. In M. Sandholm, T. Honkanen, T. HonkanenBuzalski, L. Kaartinen, \& S. Pyorala (Eds.), The Bovine Udder and Mastitis (pp. 76-82). Iyvaskyla, Finland: Gummerus Kirjapaino Oy.

18. Korhonen, H., Marnila, P., \& Gill, H. S. (2000). Milk immunoglobulins and complement factors. British Journal of Nutrition, 84(1), 75-80.

19. Krol, J., Litvinczuk, Z., Brodziak, A., \& Barlowska, J. (2010). Lactoferrin, lysozyme and immunoglobulin $\mathrm{G}$ content in milk of four breeds of cow's managed under intensive production system. Polish Journal of Veterinary Science, 13(2), 357-361.

20. Lascelles, A. K. (1979). The immune system of the ruminant mammary gland and its role in the control of mastitis. Journal of Dairy Science, 62, 154-160.

21. Lewis-Jones, D. I., Lewis-Jones, M. S., Connolly, R. C., Lloyd, D. C., \& West, C. R. (1985). Sequential changes in the antimicrobial protein concentrations in human milk during lactation and its relevance to banked human milk. Pediatric Research, 19(6), 561-565.

22. Liu, G. L., Wang, J. Q., Bu, D. P., Cheng, J. B., Zhang, C. G., Wei, H. Y., ... Dong, X. L. (2009). Factors affecting the transfer of immunoglobulin G1 into the milk of Holstein cows. The Veterinary Journal, 182, 79-85.

23. Marnila, P., \& Korhonen, H. (2002). Immunoglobulins. In Encyclopedia of Dairy Science (Vol. 3, pp. 1950-1956). Amsterdam: Academic Press. 
24. McFadden, T. B., Besser, T. E., \& Barrington, G. M. (1997). Regulation of immunoglobulin transfer into mammary secretion of ruminants. In R. A. S. Welch, D. J. W. Burns, S. R. Davis, A. I. Popay, \& C. G. Prosser (Eds.), Milk Composition, Production and Biotechnology (pp. 133-151). New Zealand: CAB International.

25. Östensson, K., \& Lun, S. (2008). Transfer of immunoglobulins through the mammary epithelium and endothelium and in the local lymph node of cow's during the initial response after intramammary challenge with E.coli endotoxin. Acta Veterinaria Scandinavica, 50(1), 1-26.

26. Quinn, P. J., Carter, M. E., Markey, B. K., \& Carter, G. R. (2000). Clinical Veterinary Microbiology. London: Mosby-year book Europe limited.

27. Rainard, P., \& Caffin, J. P. (1983). Sequental changes in serum albumin, immunoglobulin (IgG1, IgG2, IgM) and lactoferrin concentrations in milk following infusion of Esherichia coli into the udder of immunised and unimmunised cows. Annals of Veterinary Research, 14(3), 271-279.
28. Sandholm, M., \& Korhonen, H. (1995). Antibacterial defence mechanisms of the udder. In M. Sandholm, T. Honkanen, T. HonkanenBuzalski, L. Kaartinen, \& S. Pyorala (Eds.), The Bovine Udder and Mastitis (pp. 37-48). Iyvaskyla, Finland: Gummerus Kirjapaino Oy.

29. Sandholm, M., \& Pyörälä, S. (1995). Diagnostics of mastitis. Clinical examination of a mastitic cow. In M. Sandholm, T. Honkanen, T. Honkanen-Buzalski, L. Kaartinen, \& S. Pyorala (Eds.), The Bovine Udder and Mastitis (83-88). Iyvaskyla, Finland: Gummerus Kirjapaino Oy.

30. Tizard, I. R. (2000). Veterinary Immunology (6th ed.). Philadelphia: W.B. Saunders Company.

31. Watson, D.L. (1980). Immunological functions of the mammary gland and its secretion comparative review. The Australian Journal of Experimental Biology and Medical Science, 33, 403-422.

32. Zagorska, J., Ciproviča, I., \& Miķelsone, V. (2007). Baktericīdo vielu un antivielu satura izvērtējums dažādās lauksaimniecības sistēmās turēto govju pienā. Latvijas Lauksaimniecības Universitātes Raksti, 18(313), 45-50. 